\title{
Teachers' Perceptions About School Innovation Practices in Secondary Schools
}

\author{
Prof. Dr. Abid Hussain Ch. \\ Dean Faculty of Education, Professor, Institute of Education and Research, \\ University of the Punjab, Lahore Pakistan
}

Saghir Ahmad

PhD Scholar, Institute of Education and Research, University of the Punjab, Lahore Pakistan

Dr. Ayesha Batool

Lecturer (Visiting), Institute of Education and Research, University of the Punjab, Lahore Pakistan

\begin{abstract}
School innovation is the process of modern teaching by introducing new curriculum, new teaching methods and new ways of evaluation. School innovation is beneficial not only for teachers and students but also for the school administration, as the school administration will be able to keep a check and balance of innovational outputs in a friendly way. The objectives of our research were to study the school innovational practices at secondary level, teacher's perceptions and the views of public and private school teachers regarding innovation at secondary level in Lahore. The objectives have been achieved by the responses of public and private school teachers. The nature of the research was descriptive survey and quantitative approach was employed. Purposive sampling technique was used to select sample of respondents and collect data. The close ended self-developed questionnaire was filled up by 200 respondents. Descriptive statistics was applied to get the descriptive information (frequency, central tendency, and standard deviation) of respondents. Moreover, inferential statistics (t-test and one way ANOVA) were applied to know about the differences of views among different demographic variables. At the end we concluded that private school teachers pay more emphasis on school innovation then public school teachers, so the government should maintain the standards of public schools as well by keeping proper check and balance.
\end{abstract}

Keywords: School innovation, teacher's perceptions, public and private schools.

DOI: $10.7176 / \mathrm{DCS} / 10-2-01$

Publication date: February $29^{\text {th }} 2020$

\section{Introduction}

Innovation defines as the usage of new thoughts, learning and practices as well as of enriched thoughts, information and practices (Kostoff, 2003; Mitchell, 2003). Innovation is unique in relation to change or change, which does not really mean the utilization of something new, nor do they infer the use of boosted thoughts or information (King \& Anderson, 2002). It is the item or process must be brought into the commercial center with the goal that clients or different institutions and organizations can profit. This make out an innovation from disclosure. A creation or revelation upgrades the supply of information, however it does not immediately touch base in the commercial center as an undeniable novel item or process. Innovation happens at the purpose of conveying to the business advertise new items and procedures emerging from uses of both existing and new information (Beck, 2003).

Over the most recent couple of years, innovation has been progressively viewed as a pivotal factor in keeping up competition in a globalized economy. Advancement can inhale new life into moderating dormant markets, and go about as a component to upgrade any association's capacity to adjust to evolving situations (Damanpour \& Gopalakrishnan, 1998; Hargadon \& Sutton, 2000). The two arrangements and speculations on advancement have predominantly centered on the business segment. Educational institutions need to enhance to stay aware of their opposition by presenting new goods or services, enhancing the productivity of institutions, or improving the advertising of activities with a specific end goal to ensure their existence.

Business and educational institutions have accepted innovation and it became a popular and important aspect of the organizations. Because people accepted it with open heart. Government consumption in OECD nations speaks to around $48 \%$ of (GDP) overall, and now and again relates to the greater part of national GDP. Education is a vital segment of administration attention, open use on instructive establishments represented 5.3\% of national wage by and large for OECD nations (OECD, 2015). Innovations to enhance the adequacy and productivity of such a vast zone of government spending could yield critical advantages. Education is seen in many societies as a methods for increasing equity and equality. And innovation helps out to develop and improve the effectiveness and efficiency in education sectors. This is good thing for educational institutions and in addition balance in learning results. 
There are different types of school innovations. A few developments are observable to imminent guardians. Illustrative are workstations for all learners or a computerized white board. Different advancements are undetectable to untouchables. One can consider new didactical methodologies or another framework for instructor pay. There is a broad assortment of writing on school developments, however up until now, most researchers just cover one specific advancement, without considering the nearness of alternate developments that the school may consider it. Savina (2015) utilize an instrumental construct to check the cause and effect of information technology on learners' performance. The researcher noticed a noteworthy positive relationship and positive effect of technology. He also explore a positive relationship and presume that there is proof that technology utilization enhances academic performance of learners. Another study conducted by Simplicio (2004) and observed that information technology effects the academic performance of students positively. Indicators of school innovation include curriculum and teachers.

The curriculum provides students the opportunity to focus in domain areas such as the environment, international development, health care, and education. They can also shape their academic efforts based on their preferred approach to social impact, such as corporate social responsibility, social entrepreneurship, nonprofit leadership, or government. Human insight is seen universal as a great asset for the improvement of society. It is one of the fundamental conditions for the formation of exceptionally modest advancements in different fields of human movement and gives a competitive advantage and administration position for both a solitary individual and the state.

Teachers may be prepared not exclusively to devour instant instructive developments and innovations, yet additionally to make them. The current era demands more innovative and proactive work from teachers and institutions. The time has come to change from the regenerative, imaginative to inventive and creative work. There is need to learn and think new things for teachers to compete the world. They must learn not exclusively to utilize instant thoughts, yet additionally to create them. Innovative thoughts are compulsory to develop innovative environment in educational institutions. Teacher has ability to think new ideas. (Savina, 2015).

\section{Significance of Study}

This study has significance in both practical and theoretical perspectives. This research is beneficial not only for the head teachers and school administration but also for the board of education, curriculum developers, teacher trainers and other educational stakeholders. The head teachers and school administration may get benefit as they feel a positive and innovative change in school by introducing new methods of learning and teaching. From this research the school administration may be able to keep a check and balance of innovational output in the school in a friendly and creative way. Students may also provide by a healthy and creative learning environment in which they can learn in an enjoyable way.

The board of education and curriculum developers may able to produce such curriculum and the methods of teaching which is not out dated and traditional but it may be such that it can match the demands of modern society and needs of the country. The use of technology in educational process should be so common that every individual should know how to use it in a proper way. The teacher trainers get a guideline to produce teachers with innovative minds. Through this study teaching, learning and administration at secondary level may become more effective and the educational outcomes can be better and according to the requirements of the modern world.

\section{Research Objectives}

The study was conducted to achieve the following objectives to:

1. Identify the school innovation practices in secondary schools.

2. Compare the views of teachers about innovative practices on the basis of school type, gender, discipline, class, qualification and experience of respondents.

\section{Research Methodology}

The study was quantitative and survey type in nature. The population of this study included male and female teachers from both public and private secondary schools of Lahore district. A sample of 200 school teachers selected randomly. A self-developed questionnaire on five point Likert type was used to collect data from the teachers. Data were collected personally by the researchers.

Table 1

Reliability of the Scale

\begin{tabular}{cc}
\hline Cronbach's Alpha & No. of items \\
\hline .789 & 20 \\
\hline Table 1 shows that Cronath's Alpha was applied to check the reliability of the instrument.
\end{tabular}

Table 1 shows that Cronbach's Alpha was applied to check the reliability of the instrument. There were 20 statements and the reliability was .789 , which is statistical significant. Data were collected personally. Descriptive and inferential statistics were used to analyze the data. 


\section{Data Analysis}

Table 2 Demographic file of all the selected Teachers on the basis of Gender

\begin{tabular}{ccc}
\hline Gender of respondents & Frequency & Percent \\
\hline Male & 103 & 51.5 \\
Female & 97 & 48.5 \\
Total & 200 & 100.0 \\
\hline
\end{tabular}

Table 2 indicates the difference between the frequency and percentage of respondents according to their gender. The total numbers of respondents were 200.There were 103 male and 97 female teachers.

Table 3 School of Respondents

\begin{tabular}{ccc}
\hline School & Frequency & Percent \\
\hline Public & 58 & 29.0 \\
Private & 142 & 71.0 \\
Total & 200 & 100.0 \\
\hline
\end{tabular}

Table 3 shows the difference between the frequency and percentage of respondents from public and private schools. The total no of schools were 7 and 3 were public and 4 were private.

Table 4 Discipline of Respondents

\begin{tabular}{ccc}
\hline Discipline of respondents & Frequency & Percent \\
\hline Arts & 81 & 40.5 \\
Science & 119 & 59.5 \\
Total & 200 & 100.0 \\
\hline
\end{tabular}

Table 4 shows that the respondents were belonging from two groups, arts and science. Total no of respondents were 200 and 81 of them from arts group and 119 respondents from science group.

Table 5 Class of respondents

\begin{tabular}{ccc}
\hline Class & Frequency & Percent \\
\hline $9^{\text {th }}$ & 81 & 40.5 \\
$10^{\text {th }}$ & 118 & 59.0 \\
Total & 200 & 100.0 \\
\hline
\end{tabular}

Table 5 shows that how many teachers taught grade $9^{\text {th }}$ and $10^{\text {th }} .81$ teachers were taught grade $9^{\text {th }}$ that was $40 \%$. And 118 teachers were taught grade $10^{\text {th }}$ that was $59 \%$.

Table 6 Experience of respondents

\begin{tabular}{ccc}
\hline Experience of respondents & Frequency & Percent \\
\hline $0-5$ & 69 & 34.5 \\
$6-10$ & 77 & 38.5 \\
$11-15$ & 37 & 18.5 \\
16 -above & 17 & 8.5 \\
Total & 200 & 100.0 \\
\hline
\end{tabular}

Table 6 indicates the experience of all the respondents who were involved in this study. This table shows the least to highest experience of service of the respondents $34.5 \%$ respondents have $0-5$ years' experience, $38.5 \%$ respondents have $6-10$ years' experience, $18.5 \%$ respondents have $11-15$ years' experience and $8.5 \%$ respondents have 16-above years' experience.

Table 7 Qualification of Respondents

\begin{tabular}{ccc}
\hline Qualification of respondents & Frequency & Percent \\
\hline F.A. & 4 & 2.0 \\
BA/BSC & 23 & 11.5 \\
Masters & 128 & 64.0 \\
M.Phil & 43 & 21.5 \\
P.hd & 2 & 1.0 \\
Total & 200 & 100.0 \\
\hline
\end{tabular}

Table 7 shows the qualification of the respondents. After survey we came to know that $2 \%$ respondents were F.A., $11.5 \%$ were B.A/ BSC, $64 \%$ had master's degree, $21.5 \%$ respondents had M.Phil degree and P.hd teachers were $1 \%$. 
Table 8 Statistics of Teachers Responses about School Innovation Practices

\begin{tabular}{clcc}
\hline Sr. & Statements & $M$ & $S D$ \\
\hline 1. & Innovation makes learning strong and easy. & 4.0900 & 1.08062 \\
2. It is more demanding to find the new ways of teaching. & 4.1550 & .90835 \\
3. Innovation provides new topics and trends oriented learning. & 4.1550 & .91387 \\
4. Teaching innovations are now the demand of the developing society. & 4.1700 & .97769 \\
5. My teaching methods address a variety of student learning styles. & 3.9600 & .84971 \\
6. Activities in the class encourage students to develop their own skills, ideas & 4.1000 & .89105 \\
& and content mastery. & 3.9450 & .81566 \\
7. I provide opportunities for discussion to students and learn things & & .79572 \\
& effectively. & 4.2000 & 1.07974 \\
8. Students solve their study problems through discussion in classroom. & 3.9000 & 1.09471 \\
9. I share my knowledge and experiences with students. & 3.7400 \\
10. School environment is compatible for educational innovations. &
\end{tabular}

Table 8 indicates that majority of teachers agreed that teaching innovations are now the demand of the developing society $(M=4.17, S D=.97769)$ and innovation provides new topics and trend oriented learning for teachers and students $(M=4.15, S D=.91387)$. Students also solve their study problems through discussion with teachers in the classroom $(M=4.2, S D=.79572)$ and innovation is more demanding to find out the new ways of teaching $(M=4.15, S D=.90835)$. It is concluded that innovation practices help teachers to encourage students to solve their study problems by them.

Table 9 Statistics of Teachers Responses about School Innovation Practices

\begin{tabular}{|c|c|c|}
\hline Statements & $M$ & $S D$ \\
\hline $\begin{array}{l}\text { 11. My head-teacher and other colleagues encourage me to do incremental } \\
\text { innovations. }\end{array}$ & 4.0300 & .87345 \\
\hline 12. Innovation as is an essential element of educational development. & 4.1650 & .77510 \\
\hline 13. ICT plays a vital role in educational innovation & 4.0500 & .90087 \\
\hline $\begin{array}{l}\text { 14. I teach them how to take part in different activities and work well with other } \\
\text { students. }\end{array}$ & 4.0050 & 91606 \\
\hline 15. I evaluate the students in the class. & 4.0050 & .84173 \\
\hline 16. I promote ICT related skills and competencies. & 3.9150 & .85524 \\
\hline 17. I give feedback to students according to their performance. & 3.9050 & 96469 \\
\hline 18. I use student centered approach in class. & 3.8200 & 93915 \\
\hline 19. I discuss new topics understandable to the students. & 3.9550 & .88708 \\
\hline 20. I make evaluation process interesting for the students. & 4.0000 & .87397 \\
\hline
\end{tabular}

Table 9 indicates that majority of teachers agreed that teaching innovations is an essential element of educational development $(M=4.16, S D=.77510)$ and ICT plays a vital role in educational innovation $(M=4.05$, $S D=.90087)$. Teachers made evaluation process interesting for the students $(M=4.00, S D=.87397)$ and majority of teachers discuss new topics understandable to the students $(M=3.95, S D=.88708)$. It is concluded that innovation practices are the essential elements of educational development.

Table 10 Independent sample t-test was used for Difference between male and female respondents.

\begin{tabular}{lcccccc}
\hline Variable & Gender & $N$ & Mean & $S D$ & $d f$ & Sig. \\
\hline School innovation & Male & 102 & 82.69 & 8.17 & 197 & 000. \\
& Female & 97 & 77.56 & 15.16 & & \\
\hline
\end{tabular}

In table 10 independent sample t-test was used for difference between male and female respondents' teachers' perception regarding school innovation practices. The difference between the result of male $(\mathrm{M}=82.69$, $\mathrm{SD}=8.17)$ and for female $(\mathrm{M}=77.56, \mathrm{SD}=15.16)$. Resultantly, there has been significant difference between male and female perception regarding school innovation practices. It is concluded that male teachers are doing more innovational practices at secondary level in Lahore than female.

Table 11 Independent sample t-test was used for Difference between Public and Private School Respondents.

\begin{tabular}{ccccccc}
\hline Variable & School type & $N$ & Mean & $S D$ & $d f$ & Sig \\
\hline School innovation & Public & 58 & 73.63 & 17.99 & 198 & .00 \\
& Private & 142 & 82.97 & 7.65 & 65.5 & \\
\hline
\end{tabular}

In table 11 Independent sample t-test was applied for the difference between public and private school respondents. The difference between the result of public $(\mathrm{M}=73.63, \mathrm{SD}=17.99)$ and private were $(\mathrm{M}=82.97$, $\mathrm{SD}=7.65)$. There was a significant difference between the types of school. So, in the nutshell private schools are much concern with the school innovation practices then public schools. 
Table 12 Independent sample t-test was used for Difference between the Disciplines of Respondents.

\begin{tabular}{ccccccc}
\hline Variable & Discipline & $N$ & Mean & $S D$ & $d f$ & Sig. \\
\hline School innovation & Arts & 81 & 78.92 & 14.17 & 198 & .065 \\
& Science & 119 & 81.17 & 10.88 & & \\
\hline
\end{tabular}

In table 12 Independent sample t-test was used for the difference between the disciplines of respondents' teachers' perception regarding school innovation practices The difference between the scores of Arts $(\mathrm{M}=78.92$, $\mathrm{SD}=14.17)$ and Science were $(\mathrm{M}=81.17, \mathrm{SD}=10.88)$ were more significant. Resultantly, there has been no significant difference between arts and science group perception regarding school innovation practices. Both groups has different ratio in school innovation practices. In some extent science group has more involved in school innovation practices.

Table 13 Independent sample t-test was used for difference between the classes of respondents.

\begin{tabular}{ccccccc}
\hline Variable & Class & $N$ & Mean & $S D$ & $d f$ & Sig. \\
\hline School innovation & $9^{\text {th }}$ & 81 & 80.11 & 13.36 & 197 & .746 \\
& $10^{\text {th }}$ & 118 & 80.37 & 11.69 & & \\
\hline
\end{tabular}

In table 13 Independent sample t-test was used for the difference between the classes of respondents' teachers' perception regarding school innovation practices The difference between the score of class $9^{\text {th }}(M=$ $80.11, \mathrm{SD}=13.36)$ and class $10^{\text {th }}$ were $(M=80.37, \mathrm{SD}=11.69)$. There was no significant difference between the perceptions of teachers about innovational practices between $9^{\text {th }}$ and $10^{\text {th }}$ class.

Table 14 One way ANOVA for the Difference among Teachers about School Innovation Practices on the Basis of their Experience

\begin{tabular}{lccccc}
\hline & Sum of Squares & $d f$ & Mean Square & $F$ & Sig. \\
\hline Between Groups & 1077.276 & 3 & 359.092 & 2.407 & .068 \\
Within Groups & 29237.679 & 196 & 149.172 & & \\
Total & 30314.955 & 199 & & & \\
\hline
\end{tabular}

Table 14 indicates that one way ANOVA was applied to explore the difference in scores of teachers regarding school innovation practices. According to the table, the significance value $(\mathrm{P}>.05)$ among the response of the respondents with respect to their experience. Therefore, there is no significant difference among the views of respondents with respect to their experience.

Table 15 One way ANOVA for the Difference among Teachers about School Innovation Practices on the Basis of their Qualification

\begin{tabular}{lccccc}
\hline & Sum of Squares & $d f$ & Mean Square & $F$ & Sig. \\
\hline Between Groups & 643.771 & 4 & 160.943 & 1.058 & .379 \\
Within Groups & 29671.184 & 195 & 152.160 & & \\
Total & 30314.955 & 199 & & & \\
\hline
\end{tabular}

In table 15 one way ANOVA was applied for the difference in scores of teachers about school innovation practices. According to the table, the significance value $(\mathrm{P}>.05)$ among the response of the respondents with respect to their qualification. Therefore, there is no significant difference among the views of respondents with respect to their qualification.

\section{Conclusion}

From the present research it can be concluded that the perceptions of teachers regarding school innovation are changing day by day with the change in education. The private schools are giving more attention in introducing innovation and are more responsive to the demands of modern education then the public schools. The study revealed that public schools doesn't give attention on innovation as they are using traditional teaching methods but private schools are more concern with educational innovation.

The perceptions of majority of the teachers behind the school innovation are that the school should provide favorable environment and the necessary material to the teachers so that they can use innovative methods of teaching. It is also concluded that teachers of private schools are more creative and use innovative methods of teaching then the teachers of public schools due to the lack of innovational awareness. Findings of the study indicated that the male teachers are more concern about innovation then the female teachers. The teachers of science subjects give more attention to creativity then the teachers of arts discipline. Also concluded that there is no check and balance of public schools regarding innovation that's why these schools are not concern towards creativity and innovation.

\section{Discussion}

The result shows that the concept of innovation in education is now increasing day-by-day. Public and private schools are now adopting the concept of innovation in education. The expansion of private schools is majorly influencing the school innovational practices at secondary level. According to the results of the recent research the ratio of innovational practices is relatively high in private school than public schools. The teachers of private 
schools are more innovative, resultantly the progress of the private schools is better. Private schools are more concern with educational innovation. Teachers who associated with private sector, believes the learning can made efficient and durable by using innovational strategies, methods and approaches. These findings similar to some extent with the study of Savina (2015) found that private schools are more concern with educational innovation.

\section{Recommendations}

Following are the recommendations on the basis of study findings.

1. It is responsibility of Head teachers to give proper attention on innovative education at all levels by keeping in check the methods of teaching.

2. Teachers might be trained that they can use new innovative methods to teach a topic and make the dull topics interesting.

3. Teachers might be given favorable environment and proper material by the head of the school to bring innovative change.

4. Teachers may be motivated by giving awards and appreciation for bringing innovation in school.

5. Curriculum may be changed innovatively according to the demands of modern society.

6. Government may take some steps to promote innovation in public schools by conducting seminars on the importance and benefits of educational innovation.

7. There may be a proper check of private and public schools as well which will ensure the quality of educational innovation.

\section{References}

Beck, U. (2003). The theory of reflexive modernization. Problematic, hypotheses and research programme. Theory, Culture \& Society, 20(2), 1-33.

Damanpour, C., \& Gopalakrishnan, S. (1998). Theories of organizational structure and innovation adoption: The role of environmental change. Journal of Engineering and Technology Management, 15(1), 1-24.

Hargadon, A., \& Sutton, R. (2000). Building and innovation factory. Harvard Business Review, 78(3), 157-166, 217.

OECD. (2015). Education policy outlook. Paris: OECD.

Mitchell, J. M. (2003). Emerging futures: Innovation in teaching and learning in VET. Melbourne, Anta.

Kostoff, R. N. (2003). Stimulating innovation in L. V. Shavinina (eds), The international handbook on innovation, pergamon, pp. 388400.

King, N., \& Anderson, N. (2002). Managing innovation and change: A critical guide for organizations. London: Thompson.

Savina, N. N. (2015). Highbrow educational products and training future teachers to create them. In Proceedings of the International Scientific practical Conference Dedicated to the 200th Anniversary of Teacher Education in the Volga Region: Teacher Education in Russia: Past, Present, Future, Kazan, Russia 3-5 October 2012 (pp. 152 -153). Kazan: Kazan University.

Simplicio, J. S. C. (2004). Today's teachers struggle to educate a generation of students unlike any that has ever been seen before. Journal of Instructional Psychology, 31(1), 71-75. 